\title{
Proceeding
}

7th INSHS International Christmas Sport Scientific Conference, 9-12 December 2012. International Network of Sport and Health

Science. Szombathely, Hungary

\section{Parent's perception about motor-sport activity in Italian primary school}

\author{
FILIPPO GOMEZ PALOMA $\triangle$, FILOMENA AGRILLO, CRISTIANA D'ANNA \\ Department of Human, Philosophical and Educational Science, Education Science University of Salerno, Italy
}

\begin{abstract}
GOMEZ F, AGRILLO F, D'ANNA C. Parent's perception about motor-sport activity in Italian primary school. J. Hum. Sport Exerc. Vol. 8, No. Proc2, pp. S165-S179, 2013. The educational value of motor-sport activity in Italia Primary School had its full acknowledgement through a historical development that has seen the legislative evolution and scientific research to carry on together. This increase has inevitably conditioned the school that had to adapt its educational proposals to the new cultural changes. The child with his needs and his personal needs becomes the pivot around which all educational interventions. Participation in activities polyhedral investing synergistically motor, affective and cognitive became one of the guiding principles of the program to enable the student to achieve by "doing" self-awareness. The school, in this sense, must be able to recognize and appreciate the personal attitudes, and aim to strengthen them through the development of basic skills in relation to levels of perception, psychomotor and manipulative, the processes of symbolization, logical skills, expressive, communicative and social, the spatial representation and rhythm. This study was addressed to the parents was analyzing their views on physical education in schools. Such opinions may, in fact, have a strong impact on the motivation and interest of their children to discipline. The parental representations, as has been amply demonstrated in studies on the construction of gender identity, affect the natural predispositions or personal attitudes of children, the tool used for the research is the Nominal Group Technique. Its aim is to study, analyze and investigate all those elements, problems, ideas, that cannot be examined through a quantitative analysis of the facts. What makes possible the survey is its structure. It presents itself as a union of two different phases: data collection and brainstorming. The collection of data (first time) appears to be a support for brainstorming (second moment), which is the true focus of the instrument. From a global analysis of parent's statements, we perceive that: in the sport halls, children don't learn only movement and schools are not only involved about theoretical aspect; the motor activities haven't a subordinate role compared with the logical mathematic and linguistic disciplines; the motor activities, in the school, are not an extension of recreation; children learn even if they don't stay seated, because the movement is not the distraction. Body and movement encourage the cognitive development; through his body kid learn himself, others and world around. Key words: MOTOR-SPORT ACTIVITY, EDUCATION, PARENT'S PERCEPTION, PRIMARY SCHOOL.
\end{abstract}

\footnotetext{
Corresponding author. Via Ponte Don Melillo 1. Fisciano. Salerno. Italy.

E-mail: fgomez@unisa.it

7th INSHS International Christmas Sport Scientific Conference, 9-12 December 2012. International Network of Sport and Health Science. Szombathely, Hungary.

JOURNAL OF HUMAN SPORT \& EXERCISE ISSN 1988-5202

(c) Faculty of Education. University of Alicante

doi:10.4100/jhse.2012.8.Proc2.20
} 


\section{INTRODUCTION}

In the background of the evolution of motor activities, the P.D n.104 of February 12, 1985, with the approval of the new programs for primary schools, has represented a great change in the world of school education, as a result of the best cognitivist tradition of Piaget, Bruner, Gardner and oriented towards an integration of Dewey's activism. In an always changing socio-cultural background it comes the need to recover and enhance the intellectual part of the cognitive process. The child, with his/her needs, becomes the keystone around whom all the educational interventions revolve around. The participation in multifaceted activities, which synergistically involve motor, emotional and cognitive functions, is one of the main principles inspiring the programs so to allow the pupil to reach the self-consciousness through the "doing".

In this sense, the school must know how to recognize and enhance the personal skills and it must aim at strengthening them through the development of basic skills with reference to the perceptive, psychomotor and manipulative perspective, the symbolizing processes, the logical, expressive, communicative and social skills, the space and rhythmic representation. Any sort of language (linguistic, iconic, musical and gestural, bodily and mimic) (Argyle, 1992) must be stimulated and enhanced since each of them can develop the skills of thought and feelings expression and promote more complex learning processes.

Motor education is reevaluated and considered a one of the main elements of people's education. The body is no longer considered as the element to drill or train, but it's recognized as a tool of personality. Also terminology radically changes: the terms gymnastics, meant as bodily activity free from educational and formative identity, and physical education, which educationally aims at the subject's physical side, change into motor education that synthesizes the operative and cognitive side (Sibilio, 2005).

Thus the Guidelines of the Programs of 1985 (P.D. n. 104of February 12, 1985) consider motor education, like the other subjects, a very important piece of the persons and citizens' education. Unfortunately, the full application of the directives of 1985 has not been totally carried out since the pedagogic origin of the didactic innovation has found a school that was not ready yet to live an important change. Law $n$. 148 of June 5, 1990, gives more possibilities to implement the guiding principles of programs through the reform of the primary school system. In particular, art. 8 of the same law gives a new opportunity for physical activities that, in time, can represent activities of enrichment and integration of curricular teachings consistently with the educational programming and the articulation of the disciplines (Sibilio, 2001).

The turning point that gives start to a new era in the history of the Italian school is the autonomy law. Art. $\mathrm{n}$. 21 of Law n. 59 of March 15, 1997, grants legal personality and organizational and didactic autonomy to educational institutions. Through the implementation of the autonomy and a major flexibility of the project arise new opportunities for physical activities that contribute to the enrichment of the educational syllabus.

The Committee of Wise Men, set up by Minister Berlinguer and concerning the new knowledge of the school of everybody, (M.D. N. 50 of January 21, 1997, and M.D. N. 84 of February 5,1987), refers to the importance of practical experiences and the need to link the cognitive and operational aspect.

The education of the ego of the baby and his/her mind must be adapted to the current background, culture and society. The game-sport becomes an important educational means allowing creating learning environments rich of pleasant and motivating experiences. In 1997, the agreement between MPI and CONI (Protocol Agreement) defines a new cultural space in which sports federations undertake to promote sport in schools through education and training projects to be shared and adopted. 
The National Guidelines for personalized Curricula of 2003 (Pubblicalstruzione.it) promote the harmonious and integrated development of all the person's dimensions and the subsequent National Curriculum Guidelines (Indire.it) of 2007 attach "body movement and sport" a vital role in the process of the pupil's personality education. It arises a new cultural framework within which to re-consider the experience of "doing school"; a challenge that wants to find a sense in the transmission of competences, knowledge and skills by addressing each student, in respect of the person and the oneness of his/her being, towards the building of his/her personality (Gomez, 2012).

It has been recently implemented a new physical literacy project for primary schools which is presented on December 2, 2009, at the Ministry of Education by Minister Mariastella Gelmini, the President of CONI Giovanni Petrucci and the Undersecretary delegated to sports Rocco Crimi. The project foresees the entrance of teachers of physical education teachers in primary school (as experts qualified for supporting the titular teacher) who, during the curricular hours (2 hours/week) can plan and carry out educational activities aimed both at the acquisition of motor skills and active lifestyles and to use the physical and sport activity as a facilitator means for transversal approaches that have beneficial effects on the learning skills; the project is presented like a fertile period in which to try to realize the so idealized aims and objectives contained in the programmes and in the National Curriculum Guidelines.

The European Council and the World Health Organization consider fundamental the physical activities not only for the development of the personality, but also for the attainment of a good health. Therefore, Physical education at school represents an opportunity for exchanging bodily information and messages, develop and prorate emotional and cognitive skills, thus becoming the substrate upon which to build many praxic, emotional, relational, communicative and cognitive skills, The three-year National Health Plan (1999-2001) invites to: "... promote the adoption of behaviors... to increase physical activity for young people..." (Pubblicalstruzione.it). The document "International Council of Sport and Physical Education" by the UNESCO emphasizes the "quantity" of physical activity required for an adequate educational curriculum (at least 16 school hours). Currently, in almost all European countries motor, sport and physical education is compulsory throughout the whole educational path for a number of hours that is considerably higher than the annual Italian one.

Of course from 1985 to date, as the legislative framework shows, physical education in primary school has gained a deserved educational value, but unfortunately is has not always been valued in the didactic realization. There are actually contrasting opinions both in the school environment (teachers, directors, pupils) and in the family environment. Some give the motor education a positive value in the learning processes and some others, on the contrary, consider it a factor of disturbance and distraction for the acquisition of knowledge by depriving it of its effective educational and training value and giving it a marginal role. It is clear that this diversity of approach strongly affects the didactics (Damiano, 1999). It is important to emphasize that the change and affirmation of the importance of physical education in legislation has not occurred independent and isolated way. Many researchers have concentrated their works and attention to the formative and educational role of motor-sports activities within the teachinglearning process. More specifically, starting from the overcoming of the Cartesian dualism between res cogitans and res extensa, the body has been given a new dignity and it has been affirmed the concept of the psychosomatic unity of men (Damasio, 1995). 
The body is no longer just the means of "doing" but it becomes the tool for the building of knowledge, skills and personal resources since its continuous becoming and language are intelligent and communicate feelings, emotions and thoughts better than any other code; It is what creates the substrate of intermediate and higher learning which are indispensable to the processes of symbolization, classification and abstraction (Welsh, 2005). Several authors have contributed to the revaluation of the body as knowledge mediator, within an educational activity meant as building, frame, and aiming to guarantee everyone the opportunity to a complete development of the person (understood in its union of mind and body). In fact, the "attention to the physical development of the baby... never stands out from the ways of the overall psychomotricity, and the strong "synergy" that the human body always establishes with the phenomenology of his being always a psychic body" (Acone, 2005). The attention to the inseparable relationship between mind and body has been underlined, moreover, by the new disciplines of neurosciences. In particular, there have been different authors that excelled such as Donald Hebb (1949), with his theory of associative learning and cell assemblies, Damasio (1995), who emphasized the unity of body and emotions, and Joseph Le Doux (2003), who thought that the emotional charge becomes fundamental in the learning processes.

In the pedagogical field, on the other hand, it's possible to highlight the theory of multiple intelligences by Howard Gardner (1987) which recognized the value of body-kinesthetic intelligence, and the concept of emotional intelligence by Daniel Goleman (1996), who talks about the presence of two minds in the human being, one that thinks and one that hears, and both interacting in the construction of our mental life.

Recently, it has emerged a new bio-educational culture of sciences by psychomotricists such as De Ajuriaguerra (1984), Le Boulch (1979), P. Vayer (1982), who operate in a more therapeutically field. On the other hand, A. Lapierre and B. Aucouturier (1980) operate in a psychodynamic field, more linked to the educational approach and supporting the close interrelationship between emotional-affective creative, expressive and cognitive aspects.

Thus this study, in light of the so described legislative, didactic and theoretical situation, has wanted to analyze the social representations, the consideration on the motor-sport activities in the teaching/learning environments and the perception of the importance of this discipline in contributing, directly or indirectly, to the students' school profit. The attention has been totally paid to parents by analyzing their opinions on the role of motor education at school. In fact, these opinions can strongly influence their children's' motivation and interest in the discipline. Parents' representations, as it has been largely shown in the studies on the building of the genre identity, influence the natural inclinations or personal skills of their children (Ainsworth \& Bowlby, 1991).

\section{MATERIAL AND METHODS}

\section{Sample}

The research has generally involved 40 parents of two primary schools, the one of Battipaglia and the one of Castel San Lorenzo, both municipalities belonging to the Province of Salerno one different from the other for the didactic-organizational structure of their schools. The school of Castel San Lorenzo, with inadequate facilities, is open to the new demands of an always changing society. It adds different optional activities and important projects on environment, health... to the curricular didactic activities but it has not launched the project of motor literacy. 
On the other hand, the 3rd didactic circle of Battipaglia has a great variety of didactic spaces with laboratories, wide outdoor spaces and a well structured gymnasium. Moreover, from the a. y 2009/2010, the school has launched the project of motor literacy.

The research, authorizes by the Directors of the two schools, has been carried out in January/February 2012. The school directors have send the parents a communication specifying that they could decide whether to take part or not in this work. The three-hour meetings have taken place in the afternoon during different occasions like school/families meeting days and at the end of didactic activities so to spur their participation.

\section{Tool}

The tool used for the research is the Nominal Group Technique (Van de Ven \& Delbecq, 1972). Its aim is to study, analyze and investigate all those elements, problems, ideas, that cannot be examined through a quantitative analysis of the facts. It presents itself as a union of two different phases: data collection and brainstorming. The collection of data (first time) appears to be a support for brainstorming (second moment), which is the true focus of the instrument. The NGT leads to positive results when: the subject of investigation is clear enough, it's possible to articulate questions about it, the number of the sample to be tested falls within the limits of a small group. There are, however, some critics on this tool. In fact, it cannot lead to formulations of stable, durable, and scientifically proven theories and relationships. The brainstorming, which is the most important stage, investigates on the opinions, ideas, and convictions of the subjects and these do continuously evolve. However, this tool was congenial to our research. Our main goal is to study the convictions, ideas and opinions of the parents on the motor-sports activities at school. The second reason that prompted us to use this tool is the limited number of parents who decided to join the research. Respectively for both Battipaglia and Castel San Lorenzo, the number of parents participating in the research was 20. In addition, the NGT allows a qualitative research after a brief collection of quantitative data. The first moment is identified with a quantitative survey. Parents were asked to answer, in a totally subjective and individual way, to some items presented in a questionnaire (Appendix A).

The questionnaire, which has been previously tested, has been structured and self-administered so to be less intrusive. The parents have not risked of being influenced by the answers given by the others by answering individually and anonymously. The items, presented as statements, required the expression of a personal evaluation on certain aspects relating to motor-sport activities in primary school. Through the assignation of a score from 1 to 5 points, they have anonymously expressed different levels of agreement and disagreement on what they had stated in these propositions, aware that there were no right or wrong answers but only personal opinions that had an intrinsic value as revealers of a personal perception of the object of investigation.

The first data collection has been made through the use of the Likert scale, which aims to detect the attitudes of the subjects towards a given object and their positions regarding the object of investigation (Marradi, 2002). From this first quantitative analysis it's possible to notice the idea that almost all the sample shares on the object of investigation.

Afterwards, the data have been collected into tables (Appendix B) which were different according to each statement and submitted to the attention of the participants in the second stage of the research concerning a group discussion. Through a fair and responsible group discussion, each one has been able to affirm and motivate his/her opinion and express doubts and uncertainties on those of the others by asking for 
clarifications, in an effort to achieve a greater unanimity in the judgment. Contrasting opinions have provided a breeding ground for a cognitive conflict among the participants.

The discussion has mainly taken place on six out of the ten proposals, statements for which there was a greater distribution of answers by focusing the attention, in this way, on some particularly interesting and relevant aspects that have emerged in reference to the motor-sports activities.

The collected data have been then plotted in forms useful to provide a visual representation of the phenomenon in point.

The participants, arranged in a semicircle around a table, have been asked to discuss on those statements for which there was a greater variety of answers. After having withdrawn individual cards, the data have been collected in forms, through the use of specially structured tables for each statement in order to submit them to the attention of the participants and provide, in this way, a first visual representation of the phenomenon in point. The parents spontaneously and naturally got involved in the thread without the need of special requests and feeling free to express their opinions, considerations and doubts with respect to the analyzed proposals and the number of answers that each participant had given. However, only in some cases it has been necessary the intervention of the moderator (researcher) in order to draw attention to the matter in question when the participants got too distracted from other educational issues. Then for each of the analyzed statements, after the discussion, it has been hold a new vote, this time openly with a show of hands, which has made it possible to highlight any shifts in opinion relative to the previous vote and in order to outline the vision that parents have of motor activity and the role that it plays in the learning processes in a more aware way (Palumbo, 2004).

\section{RESULTS AND DISCUSSION}

The analysis of the collected data show a series of doubts and disagreements on some issues that strongly influence the parents' consideration about motor-sport activities in primary school. The first concern is about the competence of the curricular teacher; in fact, the parents of both schools show particular mistrust on the ability of the curricular teacher to properly plan the motor activities at school. Indeed, curricular teachers are considered the main responsible for the general quite bad consideration on physical activity; they do not appropriately carry it out by often sacrificing the hours that should be spent for this discipline in order to continue the work of the previous lessons. Parents, therefore, have underlined the importance of entrusting an expert the physical education school hours. The expert, in fact, would give more guarantees about the health status of children he/she would have the right experience and know how to carry out the different motor-sport activities by planning and working on them.

Another aspect that has been discussed concerns the behavioral influences that motor activity could have on children, carried out during class hours and that represents a factor of distraction or that can make them better deal with the subsequent lessons. Below you can see the results in the figures: 


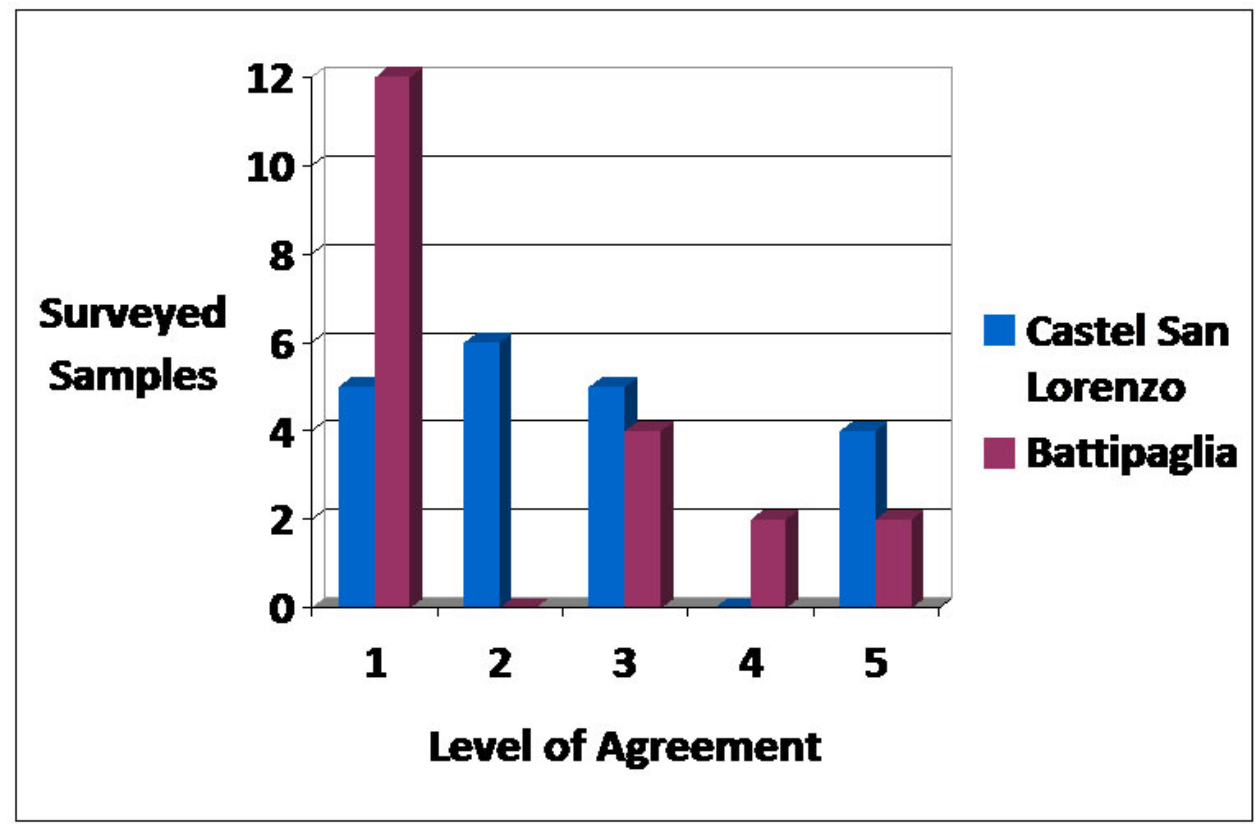

Figure 1. Distribution of the answers on the statement n.5: "Motor activities carried out in gyms require great energy and distract children from the following hours of lessons".

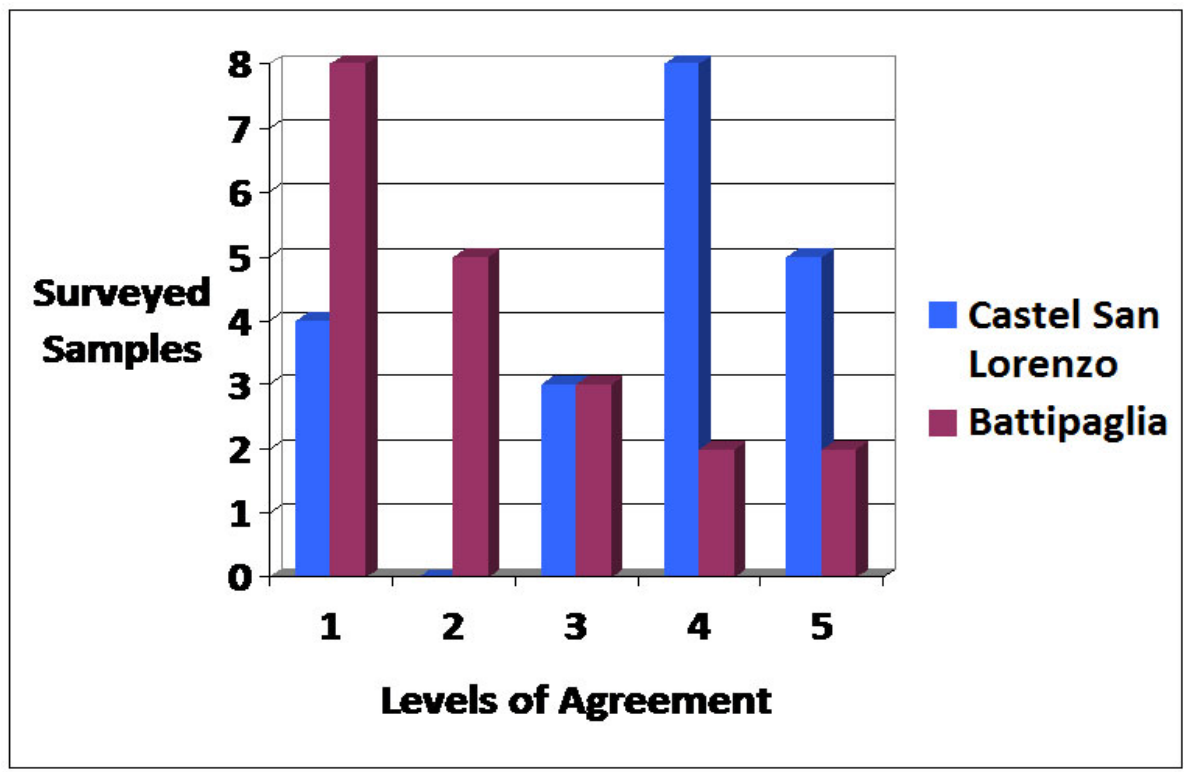

Figure 2. Distribution of the answers on the statement n.10: "Motor activities must be carried out mainly in the afternoon".

As the figures show about the negative influence that physical activities might have on children by making them lose their concentration from the conduction of the ordinary lessons, between the two surveyed groups and within them there are considerable differences of opinion and it's even possible to highlight a contrast between the groups on the location wherein the physical activities should take place during the children's regular school day. 
Since the statements are so significant in order to understand the qualitative consideration that parents have on physical activity carried out at school and outside of it, we have considered appropriate to include graphs that would allow the comparison, for each school, of the answers to the items $n .5$ and $n .10$ given by parents of the same school so to verify their degree of agreement/disagreement.

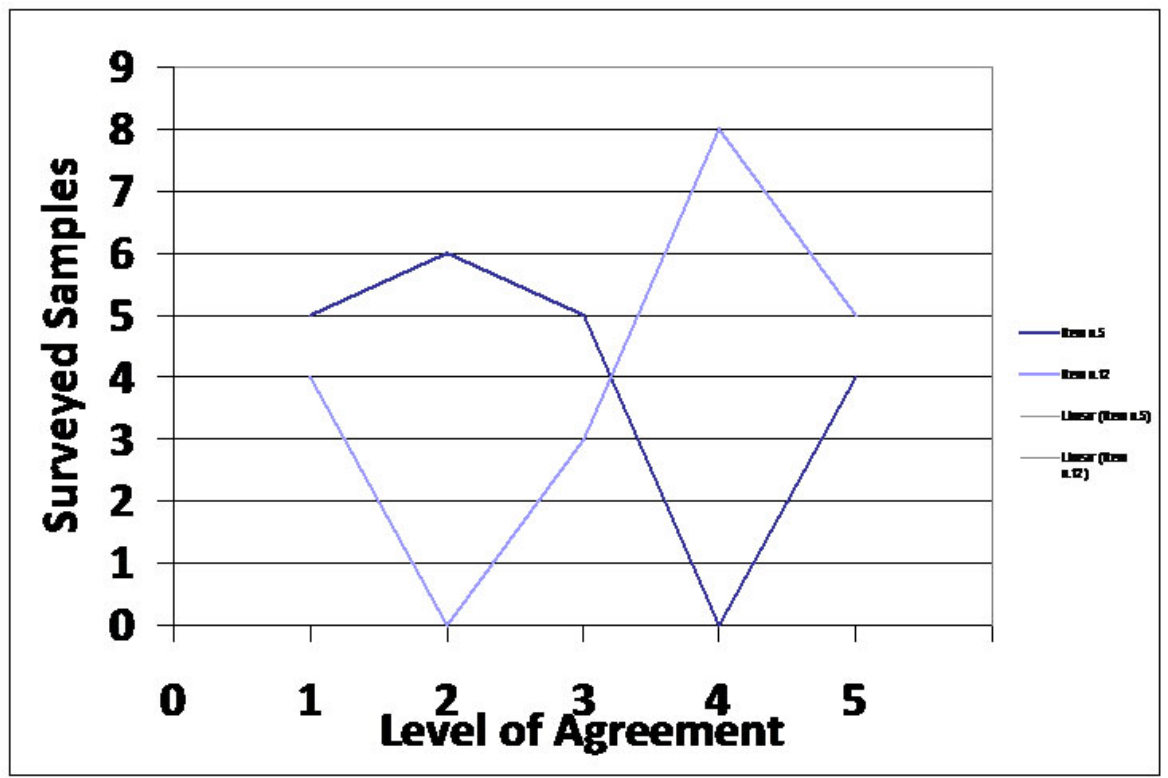

Figure 3. Cross distribution of the answers given by the parents of the school of Castel San Lorenzo to the items n.5 and n.10.

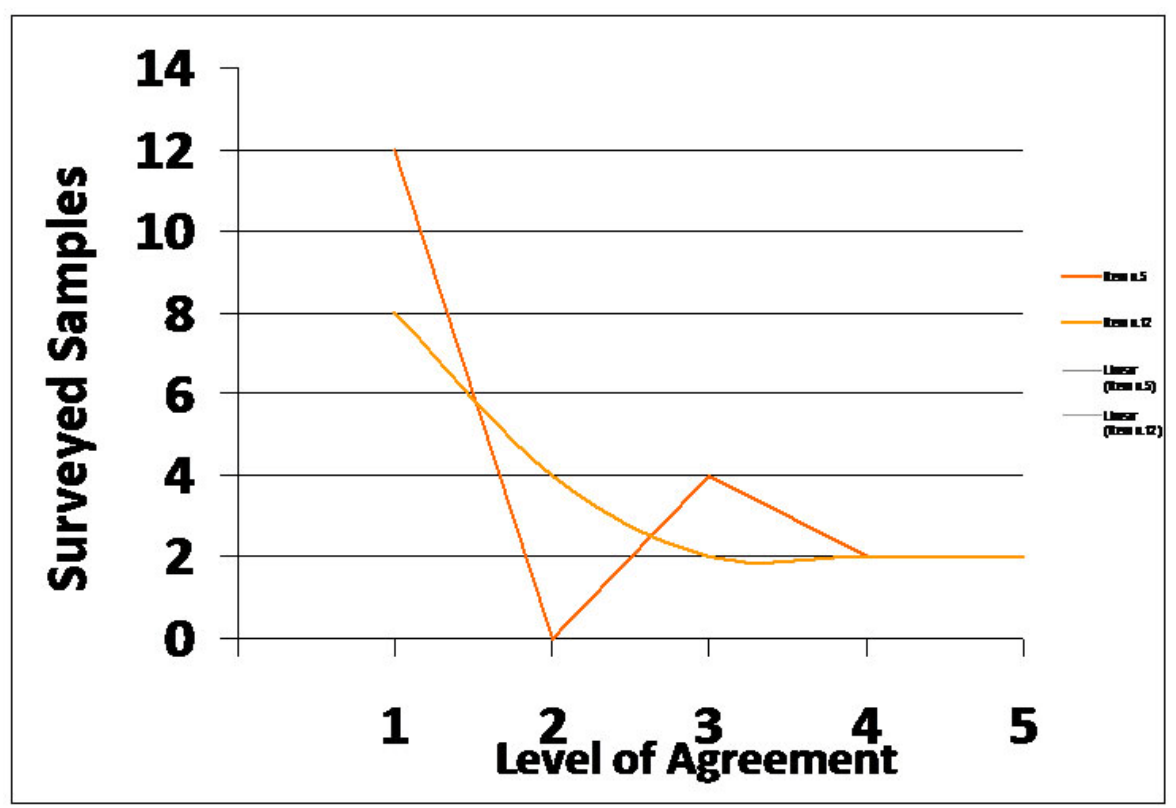

Figure 4. Cross distribution of the answers given by the parents of the school of Battipaglia to the items n.5 and $n .10$. 
As it's shown in Figures 3 and 4, in fact, despite a widespread disagreement that seems to prevail in both groups on the first statement (item n. 5), the parents of Castel San Lorenzo do most agree that physical activities should be carried out in the afternoon hours, unlike what affirm the parents of Battipaglia that show a strong disagreement also for what concerns the answers to the second statement (in fact the trendlines on the chart are almost overlapping).

For what concerns the statement n. 5 there is a greater distance between the two groups.

The parents of Castel San Lorenzo, do not have a unanimous opinion in relation to this point, since about half of the participants did not agree with the fact that motor activity is distracting for children, unlike another portion of participants that is divided between the uncertainty of the evaluations and the full agreement with the answers they have given.

The majority of the participants of Battipaglia, on the other hand, (12 completely in disagreement and 4 in uncertainty) have disagreed with the proposed statement. The discussion of the answers has been useful to clarify certain positions and to achieve greater unanimity. Most of those who have expressed a certain hesitation with respect to motor practice believe that it distracts children from the study because they let themselves go to an unbridled fun and it gives free vent to their repressed energy, so they start sweating and losing concentration that they hardly recover at the beginning of the following lesson. However, many of them do not agree with those considerations and believe that physical activity can promote the recovery of positive energy useful for the following hours of lessons.

After the debate, only those who had expressed uncertainty have changed their opinion and expressed a relative degree of agreement with the proposed statement.

By comparison with what has emerged from the discussion it is useful to make also reference to what participants have highlighted in the discussion for what concerns the statement $n .10$ (sports activities must be mainly practiced in the afternoon) of the questionnaire.

In fact, the most part of the parents of Castel San Lorenzo believes that, in order to remedy the problems raised by some parents during the discussion on the item n.5, it should be appropriate to carry out the physical activities in the afternoon or, as an alternative, in the last hour of lesson. What's surprising, however, is the lacking reference to the importance of physical activity as an alternative teaching methodology to the traditional one and the fact that it is mainly connected to the children's need to free their energies.

In Battipaglia, instead, there is a more positive consideration on the practice of physical activities during the school hours, since they're seen as a source of energy and new motivation for children.

In this particular case, during the debate, there has been also a particularly animated discussion between a mother, a former professional volleyball player who, referring to the children's natural predisposition to the movement, said that children that do not carry out activities are not healthy and that they could show problems (even supporting a school founded almost entirely on movement) and a dad who, in contrast, supported the need to prefer the education to a "motor fun". 
This discussion can be seen as emblematic for the research. Here we can find the collision of the two different opinions on the practice of motor-sport activities at school and the representation of the same educational institution. On the one hand we find the idea of a school that must invest in the motor aspect because it is part of the process of growth and development of individuals. On the other hand there is a school with exclusively cognitive ideals, where physical activities represent an obstacle to the mental development of individuals.

With respect to the need to carry out physical activities during the afternoon, however, as it's possible to notice in the image n. 4, the parents of Battipaglia and Castel San Lorenzo are in contrast since the latter believe that physical activity should be appropriately integrated in the school programming by recognizing its crucial role in the process of the child's development. From the opinions that parents have expressed it has emerged the idea that those who believe that the physical activities should be carried out in the afternoon, maybe outside the school, do not think so for a lacking consideration, but it's because they expect to receive better service from private centers and also because they give a more competitive idea of sport. Also in this case it's influent socio-economic aspect since in the municipality of Castel San Lorenzo there are not alternatives facilities to the public service structures and then they strongly need school to be able to effectively and adequately meet the needs of families, especially in the afternoon hours.

\section{CONCLUSIONS}

From a general analysis of the statements it's possible to see that:

- Gyms are not places where it's possible to merely learn movement and that schools do not just have a cognitive aim;

- The physical activity does not have a marginal and secondary role compared to the logicalmathematical and linguistic disciplines;

- $\quad$ Physical activities in schools are not an extension of recreational activities;

- Children learn although not when sitting at their desks or in perfect order because the movement is not distracting;

- $\quad$ The body and movement promote the development of cognitive skills;

- $\quad$ The child learns about himself, the others and the world around him through his/her body.

From this analysis it has emerged a large interest and a basically positive attitude towards physical activity. Despite the general trend to recognize an important role physical education, Castel San Lorenzo has appeared more linked to a traditional view of teaching by showing a greater difficulty to conceive the physical activity as an alternative methodology to the classical one that can facilitate the learning process. This is because a lack and a greater backwardness of the facilities that makes it difficult to think of learning environments different from the traditional ones, despite the desire and the awareness of the need for renewal, together with a great desire for liberation from what appears to be a disadvantage.

Battipaglia, instead, from this point of view seems to be more open to a renewal thanks to a context which is rich of new stimuli and activities that broaden the educational syllabus.

It's just here that the adherence to the physical literacy project has allowed the spread of a new way of understanding the physical activity no longer as simple exercises aimed at exercising the body but, in exchange, as a game-sport, then as a sport activity in the form of games allowing children to test new skills and attitudes and making them start respecting the rules and refining their communication and relationship skills (Sibilio, 2003). What's surprising, however, is that, despite the differences in social backgrounds, both 
groups have strongly emphasized the inadequacy and the poor skills of the curricular teacher who appears unsuitable to organize and plan physical activities at school. But the most interesting aspect that it seems appropriate to point out is the fact that, despite a greater awareness of the role that physical activity plays in the educational practice, in some cases, it is still associated with concepts such as leisure, vent and release of repressed energy, disengagement and disorder, especially in Castel San Lorenzo which is linked to an older and conservative vision of motor activity.

It is of main importance that among the various reflections it has been hardly emerged the importance of physical activity for the development of the cognitive skills, the motor schema, the lateralization and therefore its role as facilitator in the learning processes.

The survey has allowed us a review of the role of physical education at school by trying to understand how parents in particular live this dimension of learning.

In general, it is clear that to the growth of the consideration of this discipline in the scientific-cultural and legislative scenery corresponds, also on the families' part, a greater consideration of the positive significance of corporeality and a growing need for an increased quantity and proposals of motor activity at school.

It is clear that these disagreements are due to a lack of parental information on this topic and that it would be appropriate to better inform them and the same teachers who are required, anyway, a continuous training with participation in seminars and refresher courses in order to let them acquire a greater awareness of the potentialities offered by the use of the body and movement in the educational practice.

It is important that parents understand the educational-formative value of the sport practice at school, lived as the moment in which to gain cognitive learning through play and fun rather than competitiveness. It is widely showed the crucial role of parents as facilitators to introduce their children to the sport practice and then to a healthy lifestyle.

Of course, this work is not exhaustive and does not allow a deep analysis of the surveyed sample since it is numerically limited and the analysis of the attitudes of the parents represents only one part of a phenomenon that sees a series of actors, all interdependent characters, involved in the educational process of the student. There are still so many answers to be posed since there are many legislative, organizational and methodological-didactic issues linked to the motor and sport education in the Italian school, but we are sure that this work will contribute to urge greater attention to this discipline, that not just its enormous potentialities will be enhanced but, above all, that it allows the implementation of organizational measures and appropriate educational methodologies that will effectively meet the needs of a school that constantly changes and the new teaching/learning processes that the scientific research suggests us.

\section{REFERENCES}

1. ACONE G. L'orizzonte teorico della pedagogia contemporanea, Edisud Salerno. 2005.

2. AINSWORTH MS, BOWLBY J. An ethological approach to personality development. American Psychologist, 1991; 46(4): 333-341.

3. ARGYLE M. II corpo e il suo linguaggio. Studio sulla comunicazione non verbale, Bologna: Zanichelli. 1992. 
4. MINISTRY OF EDUCATION, 1997, M.D. $n^{\circ}$ 50, Italy.

5. MINISTRY OF EDUCATION, 1987, M.D. ${ }^{\circ} 84$, Italy.

6. MINISTRY OF EDUCATION, 1985, P.D. n. 104, Italy.

7. DAMASIO A. L'errore di Cartesio. Emozione, ragione e cervello umano. Milano: Adelphi. 1995.

8. DAMIANO E. L'azione didattica: per una teoria dell'insegnamento, Roma: Armando. 1999.

9. UNESCO. The International Charter of Physical Education and Sport. Parigi, 1978, on line www.unesco.org.

10. DE AJURIAGUERRA J. "Prefazione" in B. Aucouturier, I. Darrault, J. L. Empinet, La pratica psicomotoria. Rieducazione e terapia, Armando Editore: Roma. 1984.

11. GALLESE V. Embodied simulation: from neurons to phenomenal experience. Phenomenology and Cognitive Science. 2005; 4: 23-48

12. GARDNER H. Formae mentis. Saggio sulla pluralità delle intelligenze, Milano: Feltrinelli. 1987.

13. GOLEMAN D. Intelligenza emotiva, BUR Biblioteca Univ. Rizzoli. 1996.

14. GOMEZ F, SGAMBELLURI R. La disabilità tra didattica e sport, Napoli: Martano Editrice s.r.l. 2012.

15. HEBBS DO. L'organizzazione del comportamento. Una teoria neuropsicologica, Wiley: New York. 1949.

16. MINISTRY OF EDUCATION. Linee Guida per un corretto stile di vita, Italy, 2005, online http://archivio.pubblica.istruzione.it/essere_benessere/allegati/linee_guida.pdf.

17. MINISTRY OF EDUCATION. Indicazioni nazionali per I piani di studio personalizzati nella scuola primaria, Italy, 2003, online http://archivio.pubblica.istruzione.it/normativa/2003/allegati/indicazioni_primaria.pdf.

18. MINISTRY OF EDUCATION. Indicazioni per il curricolo per la scuola dell'infanzia e per il primo ciclo di istruzione, Italy, 2007, online http://www.indire.it/indicazioni/templates/monitoraggio/dir_310707.pdf.

19. LAPIERRE A, AUCOUTRIER B. La simbologia del movimento: psicomotricità ed educazione, Cremona: Padus. 1980.

20. LE BOULCH J. Educare con il movimento, Roma: Armando. 1979.

21. LEDOUX J. II cervello emotivo. Alle origini delle emozioni, Baldini Castoldi Dalai: Milano. 2003.

22. MINISTRY OF EDUCATION. Riforma dell'ordinamento della scuola elementare, Gazzetta Ufficiale: Roma, 1990.

23. MINISTRY OF EDUCATION. Delega al Governo per il conferimento di funzioni e compiti alle regioni ed enti locali, per la riforma della Pubblica Amministrazione e per la semplificazione amministrativa, Gazzetta Ufficiale: Roma, 1997.

24. MARRADI A, GASPERONO G. Costruire il dato 3. Le scale Likert, Milano: Franco Angeli. 2002.

25. MINISTRY OF EDUCATION and CONI. Protocollo d'intesa, Gazzetta Ufficiale: Roma, 2002, online http://www.edscuola.it/archivio/norme/varie/pimiur_coni_02.html.

26. SIBILIO M. Lo sport come percorso educativo. Attività sportive e forme intellettive, Guida Editore: Napoli. 2005.

27. SIBILIO M. II corpo e il movimento. Teoria, tecnica e didattica delle attività motorie per l'età evolutiva, Napoli: Cuen Editore. 2001.

28. VAN DE VEN AH, DELBECQ AL. The nominal group as a research instrument for exploratory health studies. American Journal of Public Health March. 1972; 62(3): 337-342.

29. VAYER P. Educazione psicomotoria nell'età scolastica, Roma: Armando. 1982. 


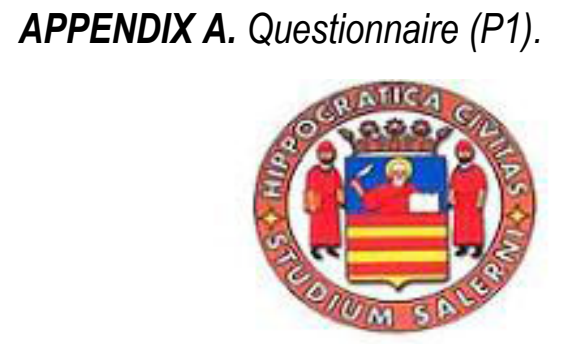

Università degí Studi di Salerno

Dipartimento di Scienze Umane Filosofiche e delia formazione

\section{QUESTIONARIO}

Gentile genitore, il seguente questionario è st at o costruito per rilevare il suo atteggiamento nei confronti delle attività motoria praticat a nella Scuola Primaria it aliana.

II suo contributo ha un'import ante valenza per la nostra ricerca.

Risponda alle domande nel modo più sincero possibile.

Per garantire l'anonimato la preghiamo di immettere un codice personale seguendo le istruzioni di seguito indicate La ringraciamo anticip at amente per il contribut o offerto.

11 tuo codice personale è com posto:

- Dal tuo giorno di nascita (anticipato dallo 0 se composto da un solo numero)

- Dal tuo mese di nascita (anticipato dalla 0 se composto da un solo numero)

- Dalfultima lettera del tuo nome di battesimo

- Dalle prime lettere del nome di battesimo di tua madre

Ecco un esempio di codice personale:

Il compleanno di Andrea è il 24 marzo e sua madre si chiama Carla.

II suo codice sarà il seguente:

\begin{tabular}{|c|c|c|c|c|c|}
\hline \multirow{2}{*}{\multicolumn{2}{|c|}{\begin{tabular}{|l|l|}
2 & 4 \\
Giorno di nascita
\end{tabular}}} & 0 & A & C & $R$ \\
\hline & & Mese di nascita & $\begin{array}{l}\text { Ultima lettera del tuo nome } \\
\text { di battesimo }\end{array}$ & $\begin{array}{l}\text { Le prime tre lette } \\
\text { madre }\end{array}$ & di tua \\
\hline
\end{tabular}

Seguendo l'esempio immett a nella seguente tabella il suo codice person ale:

\begin{tabular}{l|l|l|l|}
1 & & & \\
\hline Giorno di nascita & Mese di nascita & $\begin{array}{l}\text { Uttima lettera del tuo nome } \\
\text { dibattesimo }\end{array}$ & $\begin{array}{l}\text { Le prime tre lettere del nome di tua } \\
\text { madre }\end{array}$ \\
\hline
\end{tabular}

\section{DATI GENERAU}
1) Sesso: M? F
2) Etò:
3) Comune di residenzo:
4) Professione: Lavoratore Disoccupato
5) Ho proticoto orivitò sportivo in etó giovanile: SI? NO 


\section{APPENDIX B. Questionnaire (P2).}

\section{VALUTAZIONI}

6) Per cioscuna delle seguenti espressioni esprima il suo giudizio in bose of ilvelio di accordo/disoccordo segnondo una crocetto $(X)$ nella cosella comispondente.

Risponoa, percortesio, a tutte le offemazioni.

\begin{tabular}{|c|c|c|c|c|c|c|}
\hline & & $\begin{array}{l}\text { Perniente } \\
\text { d'accordo }\end{array}$ & $\begin{array}{c}\text { Poco } \\
\text { d'occordo }\end{array}$ & $\begin{array}{c}\text { Non } \\
\text { so }\end{array}$ & $\begin{array}{l}\text { Abbostonzo } \\
\text { d'occordo }\end{array}$ & $\begin{array}{c}\text { Compietomene } \\
\text { d'accordo }\end{array}$ \\
\hline 1 & $\begin{array}{l}\text { Per favorire l'apprendimento è necessario che i } \\
\text { bambini siano seduti ordinatamente tra i banchi, } \\
\text { il movimento è fonte di disordine e distrazione. }\end{array}$ & & & & & \\
\hline 2 & $\begin{array}{l}\text { Il corpo e il movimento possono essere utilizzati } \\
\text { per rafforzare l'acquisizione di concetti e } \\
\text { conoscenze delle altre discipline. }\end{array}$ & & & & & \\
\hline 3 & $\begin{array}{l}\text { L'insegnante curricolare non ha la preparazione } \\
\text { adeguat a per programmare le attivit à motorie } \\
\text { alf'interno dell'istituzione scolastica. }\end{array}$ & & & & & \\
\hline 4 & $\begin{array}{l}\text { L'attivit à motoria favorisce lo sviluppo delle } \\
\text { capacit à cognitive e pertanto concorre al } \\
\text { miglioramento del rendimento scolastico. }\end{array}$ & & & & & \\
\hline 5 & $\begin{array}{l}\text { Le attività motorie in palestra richiedono grandi } \\
\text { quantit à di energia, e distraggono i bambini dalle } \\
\text { ore di lezione successive. }\end{array}$ & & & & & \\
\hline 6 & $\begin{array}{l}\text { Le attività motorie e sportive creando opportunit à } \\
\text { di scambio e confronto rafforzano P'interazione } \\
\text { con i propri pari, favorendo la collaborazione, la } \\
\text { partecipazione e la consapevolezza delle proprie } \\
\text { capacità. }\end{array}$ & & & & & \\
\hline 7 & $\begin{array}{l}\text { Le palestre sono luoghi dove si apprende } \\
\text { esclusivamente il movimento, le aule sono } \\
\text { spario del cognitivo. }\end{array}$ & & & & & \\
\hline 8 & $\begin{array}{l}\text { L'attivit à motoria è una disciplina secondaria } \\
\text { rispetto alle discipline dell'area linguistica e } \\
\text { logico-matematica. }\end{array}$ & & & & & \\
\hline 9 & $\begin{array}{l}\text { L'attivit à motoria è un prolungamento della } \\
\text { ricreazione. }\end{array}$ & & & & & \\
\hline 10 & $\begin{array}{l}\text { Le attività motorie devono essere praticate } \\
\text { principalmente nelle ore pomeridiane. }\end{array}$ & & & & & \\
\hline
\end{tabular}

Grazie per l'attenzione 
Appendix C. Example of scrutiny tab used for the data discussion.

PER FAVORIRE L'APPRENDIMENTO E' NECESSARIO CHE I BAMBINI SIANO SEDUTI ORDINATAMENTE TRA I BANCHI, IL MOVIMENTO E' FONTE DI DISORDINE E DI DISTRAZIONE.
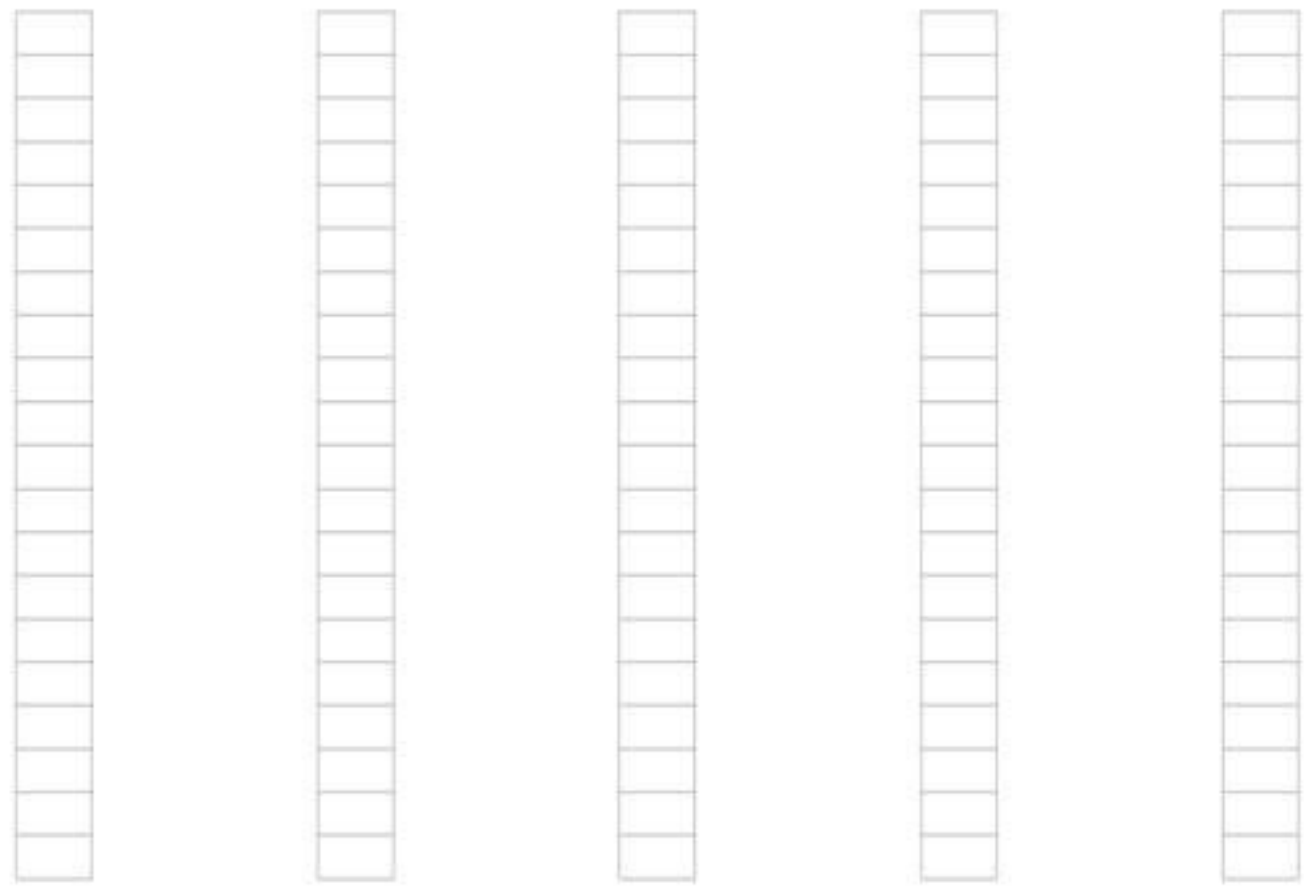

Valutazione successiva alla discussione: 